\title{
POLSKI DOROBEK NAUKOWY STEFANII ANDRUSIW: BADANIA NAD LITERATURĄ UKRAIŃSKĄ
}

\author{
Anna Woźniak \\ Katolicki Uniwersytet Lubelski Jana Pawła II \\ ORCID 0000-0003-3253-3381
}

\begin{abstract}
Streszczenie. W artykule została przybliżona sylwetka naukowa profesor Stefanii Andrusiw, literaturoznawcy i krytyka literackiego, związanej z Instytutem Filologii Słowiańskiej KUL w latach 2001-2013. Głównym wątkiem rozważań stały się badania S. Andrusiw prowadzone w Polsce, zaś celem pracy było omówienie wykrystalizowanych wówczas podstawowych kierunków działalności naukowo-badawczej Andrusiw. Tezą wyjściową artykułu było podkreślenie znaczenia fenomenu galicyjskiego w badaniach Andrusiw podjętych jeszcze podczas jej pracy na Ukrainie. Związany był z nimi zarazem namysł nad zagadnieniem tożsamości ukraińskiej, odkrywanej w literaturze ukraińskiej XX wieku. Te nowatorskie badania i poszukiwania identyfikacyjne, eksponowanie myśli niezależnej i antytotalitarnej w ukraińskich dziełach literackich, były rozwijane przez Andrusiw w Polsce. W artykule zwrócono więc uwagę na takie nurty eksploracji, jak postmodernizm, postkolonializm i intertekstualność, które profesor Andrusiw, sięgając do nowego instrumentarium metodologicznego, zaproponowała w pracach naukowych opublikowanych tak w monografiach zbiorowych, jak i w czasopismach.
\end{abstract}

Słowa kluczowe: Stefania Andrusiw, postmodernizm, postkolonializm, intertekstualność

\section{O POCZĄTKACH I ROZWOJU KARIERY NAUKOWEJ}

Profesor dr hab. Stefania Andrusiw (26.11.1942-11.08.2018) - literaturoznawca, kulturolog, krytyk literacki, członek Narodowego Związku Pisarzy Ukrainy - była profesorem Lwowskiego Uniwersytetu Narodowego im. Iwana Franki, a także wieloletnim pracownikiem Katolickiego Uniwersytetu Lubelskiego Jana Pawła II.

Stefania Andrusiw urodziła się 26 listopada 1942 roku w miejscowości Ripczyce koło Drohobycza na Ukrainie. W 1970 roku ukończyła studia filologiczne w zakresie ukrainistyki na Lwowskim Uniwersytecie Narodowym im. Iwana Franki. Jej kariera naukowa rozwijała się w wielu ośrodkach naukowych - badaczka pracowała m.in. w Lwowskim Oddziale Instytutu Literatury im. Tarasa Szewczenki oraz w swym macierzystym uniwersytecie w Kate- 
drze Czasopiśmiennictwa Zagranicznego i Informacji na Wydziale Dziennikarstwa, gdzie prowadziła wykłady z teorii i historii kultury. Doktoryzowała się w 1987 roku, a habilitację (tytuł doktora nauk filologicznych) uzyskała w 1996 roku. Jej pierwszy kontakt z Polską przypadł na lata dziewięćdziesiąte, kiedy w 1994 roku rozpoczęła pracę na Uniwersytecie Marii Curie-Skłodowskiej w Lublinie, w którym prowadziła wykłady z historii literatury ukraińskiej w Instytucie Filologii Słowiańskiej. Wtedy to miałam zaszczyt poznać prof. Andrusiw, wówczas również zaczęłam nawiązywać z nią stopniowo współpracę naukową.

Pracę etatową na Katolickim Uniwersytecie Lubelskim Jana Pawła II Andrusiw rozpoczęła 1 września 2001 roku, po uzyskaniu na Ukrainie tytułu profesora, a zakończyła ją 30 września 2013 roku. W chwili rozpoczęcia pracy naukowo-dydaktycznej w KUL została zatrudniona na stanowisku profesora nadzwyczajnego w Instytucie Filologii Słowiańskiej, a po pewnym czasie w tymże Instytucie objęła funkcję Kierownika Katedry Literatury Ukraińskiej. Podczas pracy w KUL jej dydaktyczne zaangażowanie było zróżnicowane i szerokie, prowadziła bowiem wykłady z historii literatury ukraińskiej, konwersatoria kulturologiczne, seminaria magisterskie i seminarium doktoranckie dla studentów z KUL, a zwłaszcza dla doktorantów z Europejskiego Kolegium Polskich i Ukraińskich Uniwersytetów. Od początku swego zatrudnienia na Katolickim Uniwersytecie Lubelskim Jana Pawła II Andrusiw była członkiem Rady Wydziału Nauk Humanistycznych, wchodziła także w skład wielu gremiów naukowych i komitetów redakcyjnych: Rady Naukowej „Roczników Humanistycznych (Seria: Stowianoznawstwo, z. 7), komitetu redakcyjnego pisma „Studia Ucrainica Varsoviensia”, aktywnie współpracowała także z Komisją Polsko-Ukraińskich Związków Kulturowych PAN (Oddział w Lublinie). Kilkunastoletnia praca dydaktyczno-naukowa na Katolickim Uniwersytecie Lubelskim Jana Pawła II, włącznie do 2014 roku (kiedy Prof. Andrusiw jeszcze przyjeżdżała do Lublina na obrony doktorskie), zaowocowała sporymi osiagnięciami: wypromowała ona wielu magistrów, szczególnie zaś duży okazał się jej dorobek w wykształceniu 12 doktorów, zarówno spośród Ukraińców, jak też Polaków. Wśród nich znaleźli się m.in. Andrij Savenec, Lubomir Puszak, Marta Reda (Kaczmarczyk), Edyta Moskowicz oraz Wiktoria Durkalewicz. Istotne jest to, że doktoraty przygotowywane pod kierunkiem naukowym Andrusiw bardzo często miały charakter komparatystyczny i przybliżały zagadnienia polsko-ukraińskie.

Okres 12-letniej pracy w KUL, kontakty naukowe, spotkania na płaszczyźnie zawodowej i prywatnej, pozwoliły poznać nam prof. Andrusiw jako człowieka niezwykle skromnego, osobę, która nigdy nie pretendowała do zajmowania pierwszych miejsc, a która stała raczej w szeregu za innymi. W przeciągu kilkunastoletniego okresu współpracy i koleżeńskich kontaktów miałam taką właśnie możliwość poznania również tej strony osobowości 
prof. Andrusiw. Jej szczególna wrażliwość dopełniana była przez duże poczucie humoru oraz dystans, jaki miała wobec samej siebie; zarazem jednak Andrusiw odznaczała się twardym charakterem (tego nauczyło ją nielekkie życie w ukraińskich warunkach). Wielu osobom mogłoby się wydawać, że cechowała ją nieustępliwość i postawa nieprzejednana, potrafiła bowiem walczyć zawzięcie o słuszność własnych racji w obronie swoich podopiecznych. Wynikało to z tego, że prof. Andrusiw po prostu ceniła uczciwość tak w nauce, jak i w życiu, i nie hołdowała nigdy karierowiczostwu i pozerstwu. W pracę ze swoimi uczniami angażowała się w pełni, służąc merytorycznym wsparciem, często - co dostrzegałam - kosztem własnego zdrowia, wkładając serce w naukową formację swych wychowanków. Była wymagającym, życzliwym i oddanym studentom dydaktykiem i niezwykle zaangażowanym promotorem naukowym, gotowa służyć radą i zawsze skłonna do opieki nad innymi, także na płaszczyźnie prywatnej.

\section{GŁÓWNE KIERUNKI BADAŃ NAUKOWYCH. POLSKI OKRES DZIAŁALNOŚCI BADAWCZEJ}

Niniejsze omówienie dorobku naukowego prof. Stefanii Andrusiw w żadnym wymiarze nie pretenduje do miana jego całościowego ujęcia, koncentruje się natomiast przede wszystkim na wybranych aspektach jej badań podejmowanych podczas pobytu w Polsce i pracy naukowo-dydaktycznej w KUL. Artykuł będzie zatem próbą ukazania najważniejszych - w subiektywnym oglądzie dokonań prof. Andrusiw z wielu pól jej działalności naukowo-badawczej.

Zainteresowania naukowe Andrusiw dotyczyły zwłaszcza problematyki ukraińskiej tożsamości narodowej i nakierowane były na rozpoznawanie tropów i pierwiastków kulturologicznych, a także przedstawianie tendencji rozwojowych we współczesnym ukraińskim procesie historycznoliterackim. Jej eksploracje prowadzone były w oparciu o materiał literatury ukraińskiej, głównie lat 30. XX wieku, oraz literatury najnowszej. Twórczość naukowo-badawczą prof. Andrusiw ukazują zarówno artykuły naukowe, jak też prace krytycznoliterackie, publicystyczne czy omówienia. Analizując utwory literackie, zawsze w odniesieniu kulturowym, badaczka skupiała się w swych tekstach z pierwszego okresu pisarstwa naukowego przede wszystkim na „fenomenie galicyjskim" uobecnionym w kulturze i literaturze ukraińskiej.

$\mathrm{Na}$ całościowy dorobek publikacyjny Andrusiw złożyły się liczne artykuły naukowe oraz kilka książek. Na Ukrainie opublikowała chociażby, we współautorstwie, książki monograficzne: Подорож без кіния (Podorož bez kincâ, Kiïv 1986) oraz Лimepamypa i сучастність (Literatura i sučastnist, Kiïv 1986); była też współautorem dwutomowej pracy Iсторія українській літератури XX cm. (Istoriâ ukrä̈ns'kij literaturi XX st., Kiïv 1995), 
Украінки в історії (Ukrainki v istoriï, Kiïv 2004). Jej kolejna autorska monografia Роман Іванчук. Нарис творчості (Roman Ivančuk. Naris tvorčosti) nie została jeszcze wydrukowana. Natomiast autorska książka Moдyс національної ідентичності: Львивський текст 30-х років XX cm. (Modus nacional'noï identičnosti: Lvivs'kij tekst 30-h rokiv XX st., Ternopil 2000) została na Ukrainie uhonorowana Nagrodą im. Ołesia Biłeckiego z dziedziny literaturoznawstwa i krytyki literackiej (2002 r.) i zyskała duży rezonans w środowisku naukowym.

Próbę opisu twórczości naukowej prof. Andrusiw rozpocznę zatem od uwypuklenia stałych wątków jej badań naukowych, uwidocznionych między innymi we wspomnianej monografii Modus tożsamości ukraińskiej, traktującej o tekście lwowskim lat 30. w literaturze ukraińskiej. Mowa tutaj właśnie o owym „fenomenie galicyjskim” kultury ukraińskiej, i jednocześnie „tekście lwowskim" rozumianym jako reprezentacja świadomości zachodnio-ukraińskiej, „galicyjskiej”, jako palimpsest, jak twierdziła badaczka, czyli „miejsce ustawicznego przepisywania historii i kultur”, ale zarazem „miejsce swoje”. To właśnie ów „fenomen galicyjski” stał się jednym z głównych tematów badawczych rozważanych w naukowym pisarstwie prof. Andrusiw. W moim przekonaniu pozostawał on wciąż inspirującym intelektualnie, nieustannie modyfikowanym motywem badań prowadzonych przez nią również w Polsce. We wspomnianej książce zilustrowany został, a podjęty przez ówczesnych pisarzy, dyskurs literacki Ukrainy Zachodniej, „nieskażonej”, jak podkreślała badaczka, czyli uwolnionej od ideologizowanych i imperialnych pierwiastków świadomości rosyjskiej. Czym był ten fenomen? O ile można, przypatrując się tekstom Andrusiw, eksplikować podstawowe jego wyznaczniki, oznaczał on na terenie Galicji sprzeciw wobec narzuconego Ukraińcom dyskursu totalitarnego i imperialnego, symbolizował nieustającą ich dążność do duchowej niezależności, nawet wbrew wszelkim formom dotkliwych sowieckich represji. Można sądzić, iż fenomen galicyjski, w warstwie psychologicznej, był według prof. Andrusiw uosobieniem trwania Ukrainy w kulturze narodowej, natomiast w warstwie kulturowej ucieleśniał opowiedzenie się za narodową odrębnością i suwerennością Ukraińców. W swej monografii autorka akcentowała fakt, iż proces formowania się owego galicyjskiego fenomenu psycho-kulturowego zakończył się w dwudziestoleciu międzywojennym, po porażce ukraińskich zmagań o wolność, kiedy runęły nadzieje na suwerenność. Zarazem „mit” ten upadał po straszliwym głodzie na Ukrainie w latach 1932-1933, niszczeniu inteligencji i intensyfikacji terroru Stalinowskiego w latach 30. XX wieku. Chociaż Ukraina - pisała Andrusiw - „sama była okupowana przez Polskę", chociaż przeżyła klęskę rewolucji, jednak ostała

С. Андрусів, Модус національної ідентичності: Львивський текст 30-х років XX cm, Тернопіль 2000, s. 333. 
się jedynym terenem przechowującym kulturę i narodową samoświadomość ukraińską, stała się kulturową ostoją dla zniewolonego narodu ukraińskiego ${ }^{2}$.

Działalność naukowa prowadzona w Polsce przez prof. Andrusiw koncentrowała się szczególnie na badaniu współczesnej prozy ukraińskiej i kultury ukraińskiej w perspektywie najnowszych tendencji rozwojowych literaturoznawstwa i orientacji metodologicznych współczesnej humanistyki. Toteż niektórzy interpretatorzy jej dorobku naukowego uważają, że to właśnie w Polsce nastąpiła wyrazista ewolucja i modyfikacja jej badań naukowych oraz wypracowanie swoistej unowocześnionej aparatury badawczej. Nie jest to, według mnie, teza całkiem słuszna. Owszem, jej naukowy rozwój następował, ale, jak z kolei twierdzą ukraińscy badacze, już w latach 90. na Ukrainie, w okresie ustrojowych przewartościowań, dekomunizacji i większych możliwości docierania do literatury krytycznej i teoretycznoliterackiej, szczególnie zachodniej, Andrusiw jako jedna z niewielu badaczy stosowała nowe narzędzia badawcze. W Polsce zatem pozostawała ona nadal w kręgu eksplorowania zagadnień świadomości narodowej w ukraińskiej prozie współczesnej, stosowała metody z zakresu ujęć postmodernistycznych, intertekstualności, praktyk narratologicznych, jak też odwoływała się do badań postkolonialnych. Można zatem powiedzieć, że w Polsce dokonała się nie tyle ewolucja, ile pewne przeorientowanie, zmiana akcentów w podejściu metodologicznym i używanym przez prof. Andrusiw instrumentarium badawczym. Wyróżnikiem jej warsztatu naukowego było podejście kulturowe, wnikanie w sensy utworu literackiego osadzonego w przestrzeni historycznej, kulturowej i społecznej, co pozwalało badaczce na skondensowany opis rozważanych zagadnień i syntetyzowanie problematyki.

Stefania Andrusiw okazała się w swych tekstach jednocześnie znakomitym analitykiem sytuacji kulturowo-egzystencjalnej literatury ukraińskiej, kiedy rozpościerała fakty literackie na płaszczyźnie wydarzeń historii i życia literackiego, interpretując je tak diachronicznie, jak i synchronicznie. Eksponowała, podobnie jak i inni literaturoznawcy ukraińscy, wartość modernistycznej literatury ukraińskiej przełomu wieków XIX i XX, podnosiła rangę pisarstwa takich autorów, jak m.in. Wasyl Stefanyk, Łesia Ukrainka, Olha Kobylańska czy Mychajło Kociubyński, wznosząc na poziom literatury światowej i akcentując europejski wymiar ich twórczości. Co ważne, potrafiła dostrzec w literaturze tego okresu motywy buntu i anty-imperialny sprzeciw (Mykoły Chwylowego, Hryhorija Kosynki, Borysa Antonenki-Dawydowycza, Mykoły Kulisza). Waloryzacja twórców niezależnej myśli to wyraźny znak odnowionego spojrzenia Andrusiw na literaturę okresu tzw. „radzieckiej literatury ukraińskiej" i oczywiste dezawuowanie twórczości zsowietyzowanej tych autorów, którzy jawnie sympatyzowali z władzą. Podkreślić należy, że dorobek naukowy Andrusiw cechuje się intelektualną energią, ciągłym po-

2 Ibidem, s. 9. 
szukiwaniem, dużym krytycyzmem wobec badanej materii literackiej i zindywidualizowanym oryginalnym ujęciem.

Metoda badań postkolonialnych została zaprezentowana w kilku tekstach prof. Andrusiw, m.in. w artykule Relacje polsko-ukraińskie z perspektywy Postkolonial Studies. Badaczka, uznając kulturę ukraińską do czasu odzyskania niepodległości za skolonizowaną ${ }^{3}$, skupiała się w swych tekstach naukowych na kwestiach obejmujących pisarstwo tych prozaików i te zjawiska literackie, jakie przekraczały ideologiczny kanon, wychodziły daleko poza totalitarną kulturę sowiecką, także w trudnych czasach zniewolenia. Chodziło zwłaszcza o ukazanie bolesnego doświadczenia kultury ukraińskiej lat 30. i tragicznego zjawiska „rozstrzelanego odrodzenia” (termin Jerzego Giedroycia). Podejście postkolonialne tak w badaniach literaturoznawczych, jak i wypracowane również w najnowszej literaturze ukraińskiej, przez Andrusiw rozumiane było jako stanowcza obrona prawa Innego, w tym wypadku zatem prawa Ukraińców, do posługiwania się własną narracją o Historii.

Problematyce tożsamościowej w ujęciu badań postkolonialnych poświęcony był także wcześniejszy tekst badaczki pt. Тоталітаризм і культура: український досвід духовного самозбереження (Totalitarizm i kul'tura: ukrä̈ns 'kij dosvid duhovnogo samozberežennâ). Odsłonił on interesujące spojrzenie autorki na problem podwójnej kolonialnej świadomości ukraińskiej w okresie totalitaryzmu i kolonializmu. Stefania Andrusiw ukazała tutaj konieczność istnienia owej podwójnej postawy, a więc „ukrytej nienawiści do systemu totalitarnego i pozornej lojalności wobec niego"4, niezbędnej dla przetrwania narodu w przestrzeni kulturowej oraz mentalnej w celu ocalenia kultury ukraińskiej i ugruntowania jej narodowej tożsamości. Analogie do zjawiska Ketman, o jakim pisał Czesław Miłosz w Zniewolonym umyśle (1953), w odniesieniu do polskich realiów sowieckiej ideologicznej i mentalnej indoktrynacji Polaków, wydają się w tym momencie oczywiste. A tę nową opowieść o sytuacji ukraińskiej, twierdziła prof. Andrusiw, proponowała właśnie najnowsza literatura ukraińska, w której następowało zdekonstruowanie świadomości totalitarnej i kolonialnej po to, by odnaleźć zdefiniowaną od nowa, uwolnioną od przedawnionych ideologicznych miazmatów, kulturę ukraińską. Wrażliwość Andrusiw na problemy Ukrainy w sferze kulturalnej i społeczno-politycznej nie mogła pozostawić jej obojętną wobec cierpień ukraińskich pisarzy walczących z reżimem totalitarnym; badaczka nie mogła pominąć tragicznego doświadczenia batalii twórców o zachowanie kultury, sfery duchowej i suwerenności.

S. Andrusiw, Relacje polsko-ukrainskie z perspektywy Postkolonial Studies, „Roczniki Humanistyczne" 2011, z. 7: Stowianoznawstwo, t. LIX, s. 61-62.

4 С. Андрусів, Тоталітаризм і культура: украӥнський досвід духовного самозбереження, [w:] Wschód i Zachód: w poszukiwaniu Europy duchowej, red. M. Ołdakowska-Kuflowa, M. Stebler, A. Woźniak, Lublin 2006, s. 114. 
Stefania Andrusiw pisała:

Ukraińska kultura, literatura, jak też całe społeczeństwo, wyszły z objęć imperium totalitarnego spustoszone, zniszczone bardziej niż kultura rosyjska czy nawet inne kultury kolonialne, jednak Ukraina zawsze była obiektem szczególnego zainteresowania reżymu totalitarnego, jakie można opisać za pomocą znanego porzekadła: „Kiedy w Moskwie obcinają paznokcie, to w Kijowie ucinają palce 5 .

Postmodernistyczny horyzont badawczy został z kolei zademonstrowany w wielu innych tekstach prof. Andrusiw. Jednym z pierwszych był artykuł Цитування «реальності» в украӥнському літературному постмодернізмі (Cituvannâ «real'nosti» $v$ ukrä̈ns'komu literaturnomu postmodernizmi), w którym zagadnienie intertekstualności, a zwłaszcza cytaty z klasycznej literatury ukraińskiej w utworach współczesnych (np. Дванадиять обручів, 2003) [Dvanadcat' obručiv] Jurija Andruchowycza) określone zostały przez autorkę jako ,postmodernistyczna reanimacja” literatury dawnej ${ }^{6}$, gdyż przybierały formę mistyfikacji, ironii, parodii i gry literackiej. Uznanie zaś w tej pracy postmodernizmu za współczesny „neohumanizm”, obejmujący złożone problemy, jakie nękają współczesnego człowieka, włącznie z problemem śmierci, było wówczas odkrywczym stwierdzeniem Andrusiw. Odważnie konstatowała ona ewoluowanie ukraińskiego postmodernizmu i jego rozwój od zjawiska dosyć infantylnego ku jakże istotnemu neohumanizmowi:

[...] [postmodernizm] ewoluował, zaryzykuję stwierdzenie, ku postmodernistycznemu neohumanizmowi, dzięki któremu człowiek, ze wszystkimi swymi słabościami i fragmentarycznością, tekstami i kontekstami, śmiesznymi i tragicznymi, swoim życiem i nawet śmiercią, mimo wszystko nadaje sens dwunastu czy też może jeszcze większej ilości obręczy owej pstrokatej realności, w jakiej przyszło mu żyć7.

Refleksje na temat historii, ujmowanej wedle postmodernistycznej interpretacji Historii, pojawiły się $\mathrm{w}$ artykule Постмодерністська концепція історії і сучасна украӥнська проза (Postmodernists'ka koncepciâ istoriï i sučasna ukraïns'ka proza), zamieszczonym w tomie Wokót problemów Histo$\mathrm{rii}^{8}$. Na materiale zaczerpniętym m.in. z utworów Andruchowycza czy Wasyla

\footnotetext{
$5 \quad$ Ibidem, s. 112. Wykorzystywane w artykule cytaty w języku ukraińskim przytaczane są w przekładzie własnym autorki artykułu na język polski.

6 С. Андрусів, Цитування «реальності» в українському літературному постмодерmiзмi, [w:] Intertekstualność w literaturach i kulturach stowiańskich, red. I. Kowalska-Paszt, M. Kuczyńska, J. Czaplińska, A. Wątorski, Szczecin 2006, s. 225.

Ibidem, s. 231.

8 С. Андрусів, Постмодерністська кониепиія історії $і$ сучасна украӥнська проза, [w:] Wokót problemów Historii. Studia o kulturze i literaturach wschodniostowiańskich, red. A. Woźniak, Lublin 2008, s. 97-105.
} 
Kożelanki przedstawiona została wizja historii w estetyce ponowoczesnej. Zatem historia, twierdziła Andrusiw, objawiła się w ujęciu prozaików ukraińskich jako forma narracji o niej, zaistniała jako opowieść w różnych werbalnych wersjach, i najczęściej wyrażona była $\mathrm{w}$ formie gry $\mathrm{z}$ historią, ironii i parodii. Z kolei w tekście Авангардизм і постмодернізм: проблема розрізнення кодів (Avangardizm i postmodernizm: problema rozriznennâ kodiv) znalazły się wnikliwe rozważania na temat konfrontacji modernizmu i postmodernizmu w kulturze ukraińskiej lat 90 . XX wieku. Była to równocześnie próba zaakcentowania własnej pozycji badaczki w sporach o istnienie postmodernizmu w literaturze ukraińskiej. Ówczesna teza Ołeha Ilnyckiego głosiła bowiem, że postmodernizm właściwy jest jedynie dla tych społeczeństw, w jakich miał miejsce rozwój industrialny, a więc nie można mówić o postmodernizmie na Ukrainie, gdzie tego rozwoju nie było. Z kolei Marko Pawłyszyn, przeciwnie, uznawał istnienie postmodernizmu w ukraińskim procesie literackim. Kwestie te zostały rozwinięte poprzez erudycyjny dyskurs historycznoliteracki Andrusiw, która, podobnie jak Tamara Hundorowa, określiła się jako zwolenniczka tezy pozytywnej, podkreślającej występowanie pre-postmodernistycznych i postmodernistycznych zjawisk u wielu twórców ukraińskich, m.in. w utworach Jurija Andruchowycza, Oksany Zabużko czy Iryny Karpy9.

A zatem w polu uwagi badaczki znalazły się przemiany, czy nawet, można powiedzieć, kulturowy zwrot literatury ukraińskiej w okresie wychodzenia spod „obręczy” sowieckiej dominacji. Częstokroć prof. Andrusiw powracała do tych zagadnień, gdyż rany i cierpienia zniewolonej literatury ukraińskiej bardzo ją bolały. Widać to w jednym z jej ostatnich artykułów pt. Współczesne literaturoznawstwo ukraińskie. Sytuacja nieustajacego „,między”, opublikowanym po polsku w lubelskiej „Tece Komisji Polsko-Ukraińskich Związków Kulturowych". Ponownie nakreśliła autorka w sposób bardzo erudycyjny, w perspektywie postkolonialnej i historii pamięci, obraz zniewolonej literatury ukraińskiej XX wieku i literaturoznawstwa ukraińskiego, które przemawiało „,głosem władzy”. Przebija w tym tekście zatroskanie Andrusiw oraz badawczy zamiar zdiagnozowania tendencji rozwojowych współczesnego procesu historycznoliterackiego i literaturoznawstwa na Ukrainie. Dlatego też w artykule zawarte zostały „porady” dla literaturoznawców dotyczące tego, w jaki sposób można ostatecznie zerwać ze stanem „między”, a więc między starymi skostniałymi metodami badawczymi i nowymi narzędziami oraz nową możliwością odczytania literatury ${ }^{10}$. Ustanowienie właściwego kanonu

\footnotetext{
9 С. Андрусів, Авангардизм і постмодернізм: проблема розрізнення кодів, [w:] W kregu kultury i historii Stowian Wschodnich. Studia dedykowane profesorowi Stefanowi Kozakowi w 70. rocznice urodzin, red. M. Kawecka, A. Nowacki, L. Puszak, Lublin 2008, s. 107.

10 S. Andrusiw, Wspótczesne literaturoznawstwo ukraińskie. Sytuacja nieustającego „,mię$d z y ”$, „Teka Polsko-Ukraińskich Związków Kulturowych” 2013, z. VIII, s. 62-64.
} 
literackiego, napisanie niezakłamanej, prawdziwej historii literatury ukraińskiej, zmiana horyzontów teoretycznych i metodologicznych, oto są wskazania i zadania dla literaturoznawców według prof. Andrusiw. Jest to, bez wątpienia, jeden z najwartościowszych jej tekstów, o wielkiej sile badawczej, stanowiący zarazem wypowiedź inspirującą do dyskusji.

Pobyt w Polsce mocno wyczulił badaczkę na sprawy polskie, z pewnością przyniósł możliwość wnikliwego spojrzenia na relacje i dialog ukraińsko-polski, czemu dała wyraz w swych pracach, a także w częstych rozmowach i dyskusjach na tematy dotyczące Polski i Ukrainy. Ową postkolonialną i zarazem antropologiczną perspektywę, a ponadto kwestie polsko-ukraińskie, dostrzec można w artykule „Себе побачити, як в люстрі”. Дещо про антропологічну природу транскордонніх перемещень (,, Sebe pobačiti, âk v lûstri”. Deŝo pro antropologičnu prirodu transkordonnih peremeŝen'). Przybliżono w nim zagadnienie antropologii podróży na podstawie esejów Andrzeja Stasiuka, Pawła Laufera i Andruchowycza, rozpatrzono mentalne i antropologiczne klisze, cywilizacyjne różnice między kulturami polską i ukraińską. Stefania Andrusiw, co należy zaznaczyć, aprobująca tezę o polskim udziale w kolonizacji Ukrainy, w swych rozważaniach doskonale naświetliła odwrotność tego doświadczenia, jego drugą, pozytywną stronę. Antropologia podróży bowiem pozwala na przekraczanie granic, obcowanie z językiem, kulturą, życiem codziennym i obyczajami innych narodów, a więc daje szansę poznawania Innego, rozpoznawania różnic i podobieństw, czyli ,ujrzenia samego siebie niczym w lustrzanym odbiciu". Warto tu przytoczyć słowa Andrusiw przełamane przez myśl Andruchowycza: „Polska była przykładem dla Ukrainy, gdyż zawsze «dobrze jest mieć obok siebie jakąś pomocną krainę marzeń, jeśli nie jako wzorzec do naśladowania, to przynajmniej jako obiekt do zazdrości»"11.

Udział prof. Andrusiw w projekcie nr 11H 11010880 w ramach Narodowego Programu Rozwoju Humanistyki (moduł 1.1.): „Literatura polska i życie kulturalno-literackie Polaków od 1864 roku na ziemiach obecnej Ukrainy" również świadczy dobitnie o dużym znaczeniu problematyki relacji polsko-ukraińskich w prowadzonych przez nią badaniach naukowych nad kulturą i literaturą. Zaowocował on artykułem Bez ojczyzny: polskie życie kulturalne w Ukraińskiej Socjalistycznej Republice Radzieckiej w latach 1920-1930 (z perspektywy ukrainskiej) ${ }^{12}$, w którym autorka w sposób kom-

11 С. Андрусів, „Себе побачити, як в люстрі”. Дещо про антропологічну природу транскордонніх перемещень, [w:] Między Wschodem a Zachodem. Z dziejów kultury pogranicza polsko-wschodniosłowiańskiego, red. W. Kołbuk, A. Nowacki, L. Puszak, Lublin 2010, s. 161

12 S. Andrusiw, Bez ojczyzny: polskie życie kulturalne w Ukraińskiej Socjalistycznej Republice Radzieckiej w latach 1920-1930 (z perspektywy ukraińskiej), [w:] Polskie życie kulturalno-literackie od 1864 roku na ziemiach obecnej Ukrainy, red. M. Ołdakowska-Kuflowa, Lublin 2017, s. 179-213. 
petentny ukazała intencje oraz metody działania komunistycznej władzy wobec języka i kultury polskiej w dwudziestoleciu międzywojennym. Polityka reżimu stopniowo doprowadziła nie tylko do zamknięcia wszelkich legalnych ścieżek rozwoju kultury polskiej mniejszości w ZSRR, ale w końcu do rozpoczęcia realizacji planów „likwidacji «szkodliwego narodu»-ludności polskiej"13 - co bardzo dobitnie wybrzmiało w pracy solidnie podbudowanej materiałem źródłowym.

Warto zwrócić uwagę na jeszcze jeden artykuł prof. Andrusiw, oparty na innej bazie materiałowej, mianowicie Антропологія простору в українській дилогії Миколі Гоголя (,,Вечера на хуторе близь Диканьки”, „Миргоpod”) (Antropologiâ prostoru v ukraïns'kij dilogiï Mikoli Gogolâ (,, Večera na hutore bliz' Dikan 'ki”, „,Mirgorod")) $)^{14}$. Stefania Andrusiw w swej oryginalnej pracy przedstawiła Gogola - którego twórczość wciąż wpisuje się w otwarte polemiki na temat identyfikacji narodowej pisarza - jako twórcę z podwójną tożsamością: ukraińską i rosyjską. Wyodrębniła nawet trzeci jej wariant - włoski, co okazuje się już mniej przekonujące, chociaż inni interpretatorzy twórczości pisarza również wysoko waloryzują pierwiastek włoski w formowaniu jego estetyki ${ }^{15}$. Podjęła Andrusiw próbę pogodzenia tych wciąż żywych w kręgach naukowych antynomii dotykających postaci Gogola, dwoistego jako twórcy i człowieka, z pochodzenia Ukraińca, który związał się świadomie z glebą kultury rosyjskiej, zwłaszcza w jej petersburskim wariancie. Ta ukraińska tożsamość, twierdziła badaczka, ujawniała się szczególnie na poziomie świata archetypowo-mentalnego i językowego - uwidaczniała się poprzez mity, folklor ukraiński i sposoby kreowania przestrzeni, zaś owa rosyjska tożsamość zaistniała jako „ruskość” i imperialność.

Profesor Andrusiw zapisała się w pamięci większości pracowników Instytutu Filologii Słowiańskiej KUL jako doskonała badaczka literatury i kultury ukraińskiej, wyróżniająca się erudycją pasjonatka oraz znawczyni orientacji metodologicznych współczesnej humanistyki. Była, niewątpliwie, naukowym autorytetem, wysoce cenionym zarówno w Polsce, jak i na Ukrainie. Jak twierdzą ukraińscy literaturoznawcy, to właśnie prof. Andrusiw jako jedna z pierwszych i nielicznych wówczas w latach 90. badaczy, rozpoczęła na gruncie ukraińskim analizowanie literatury i kultury w horyzoncie najnowszych metodologii nurtu postmodernistycznego, uprawiania badań

\footnotetext{
13 Ibidem, s. 204.

14 С. Андрусів, Антропологія простору в украӥнській дилогї Миколі Гоголя (,,Вечера на хуторе близь Диканьки”, „, Миргород”), „Roczniki Humanistyczne” 2009, z. 7: Stowianoznawstwo, t. LVII, s. 41-51.

15 Dla porównania przypomnę, że Abram Terc (Andriej Siniawski) w eseistycznej książce В тени Гоголя, [w:], Собрание сочинений в двух томах, t. II, Москва 1992, ujmował Italię w życiu i twórczości pisarza w podwójnym wymiarze: jako „lustrzane odbicie ojczyzny”, ale zarazem jako jej przeciwstawienie.
} 
W aspekcie ponowoczesności. W stosunkowo hermetycznym - wobec „nowinek" metodologicznych - literaturoznawstwie Ukrainy było to zjawisko nowatorskie. Przy czym, trzeba zaznaczyć, badaczka traktowała nowe narzędzia opisu i interpretacji dzieła literackiego jako konieczne w badaniach, a nie tylko jako nowomodne metody czy jedynie formalną matrycę. Dopowiem jeszcze, że pojmowała te współczesne orientacje humanistyki literaturoznawczej zawsze z dużą dozą krytycyzmu i przydawała im przeważnie własną interpretację.

Warto jeszcze podnieść jeden ważny rys jej osobowości, a więc to, że prof. Andrusiw, Ukrainka i patriotka, ceniła bardzo dziedzictwo kultury polskiej, dobrze opanowała język polski, stała się niekwestionowanym promotorem polskości, zawsze ważyła racje $\mathrm{w}$ dialogu polsko-ukraińskim i z przekonaniem opowiadała się najczęściej po stronie Polski. W mojej pamięci na trwałe zapisały się wspomnienia o naszym udziale w historycznej i przejmującej pożegnalnej ceremonii śp. Prezydenta Lecha Kaczyńskiego i Marii Kaczyńskiej na placu marsz. Józefa Piłsudskiego w Warszawie 17 czerwca 2010 roku, po tragedii katastrofy smoleńskiej. Pamiętam wspólne przeżywanie i ogromny żal oraz współczucie prof. Andrusiw dla Polaków po tej niepowetowanej narodowej stracie.

Niewątpliwie prof. Stefania Andrusiw zapisała ważną kartę w polskich badaniach ukrainoznawczych.

\section{BIBLIOGRAFIA}

Andrusiw Stefania. 2000. Modus nacional'noï identičnosti: Lvivs'kij tekst 30-h rokiv XX st., Ternopil' [2000. Модус національної ідентичності: Львивський текст 30-х років XX cm., Тернопіль].

Andrusiw Stefania. 2006. Cituvannâ «real'nosti» v ukraïns'komu literaturnomu postmodernizmi. W: Intertekstualność w literaturach i kulturach słowiańskich, red. I. Kowalska-Paszt, M. Kuczyńska, J. Czapliński, A. Wątorski, Szczecin: 221-231 [Цитування «реальності» в українському літературному постмодернізмі]

Andrusiw Stefania. 2006. Totalitarizm i kul'tura: ukraïns 'kij dosvid duhovnogo samozberežennâ. W: Wschód i Zachód: w poszukiwaniu Europy duchowej, red. M. Ołdakowska-Kuflowa, M. Stebler, A. Woźniak, Lublin: TN KUL: 105-114 [Тоталітаризм і культура: украӥнський досвід духовного самозбереження].

Andrusiw Stefania. 2008. Avangardizm i postmodernizm: problema rozriznennâ kodiv. [w:] W kręgu kultury i historii Stowian Wschodnich. Studia dedykowane profesorowi Stefanowi Kozakowi w 70. rocznicę urodzin, red. M. Kawecka, A. Nowacki, L. Puszak, Lublin: Wydawnictwo KUL: 97-109 [Авангардизм і постмодернізм: проблема розрізнення кодів].

Andrusiw Stefania. 2008. Postmodernists 'ka koncepciâ istorï i sučasna ukraïns 'ka proza. W: Wokót problemów Historii. Studia o kulturze i literaturach wschodniostowiańskich, red. A. Woźniak, Lublin: TN KUL: 97-105 [Постмодерністська конщепиія історії і сучасна українська проза]. 
Andrusiw Stefania. 2009. Antropologiâ prostoru v ukraïns'kij dilogii Mikoli Gogolâ (,, Večera na hutore bliz' Dikan 'ki”, ,,Mirgorod”), „Roczniki Humanistyczne”, z. 7: Słowianoznawstwo, t. LVII: 41-51 [Антропологія простору в українській дилогії Миколі Гоголя (,,Вечера на хуторе близь Диканьки”, ,,Миргород”)].

Andrusiw Stefania. 2010. „Sebe pobačiti, âk v lûstri”. Deŝso pro antropologičnu prirodu transkordonnih peremeŝen'. W: Między Wschodem a Zachodem. Z dziejów kultury pogranicza polsko-wschodniosłowiańskiego, red. W. Kołbuk, A. Nowacki, L. Puszak, Lublin: Wydawnictwo KUL: 155-168 [„Себе побачити, як в люстрі”. Дещзо про антропологічну природу транскордонніх перемещень].

Andrusiw Stefania. 2011. Relacje polsko-ukraińskie z perspektywy Postkolonial Studies, „Roczniki Humanistyczne”, z. 7: Stowianoznawstwo, t. LIX: 61-69.

Andrusiw Stefania. 2013. Wspótczesne literaturoznawstwo ukraińskie. Sytuacja nieustajacego ,między”, „Teka Polsko-Ukraińskich Związków Kulturowych”, z. VIII: 58-68.

Kaczmarczyk Marta. 2018. Andrusiw Stefania. W: Encyklopedia 100-lecia KUL, t. I, Lublin: Wydawnictwo KUL: 14.

Tarnašins'ka Lûdmila Bronislavivna, Andrusiv Stefaniâ Mikolä̈vna (Andrusiv Stefania Mikolajivna). W: Enciklopediâ Sučasnoï Ukraïni, http://esu.com.ua/search_articles. php?id+44269 [dostęp 5.09. 2018]. [Тарнашинська Л. Б., Андрусів Стефанія Миколаївна (Andrusiv Stefania Mikolajivna), [w:] Енциклопедія Сучасної Украӥни].

\section{POLISH SCHOLARLY ACHIEVEMENT OF STEFANIA ANDRUSIW RESEARCH ON UKRAINIAN LITERATURE}

Summary. The article is a scholarly profile of Professsor Stefania Andrusiw, a professor of literature and literary critic, a member of staff of the Institute of Slavic Philology of John Paul II Catholic University of Lublin in 2001-2013. The article concentrates on the main strands of Andrusiw's research conducted in Poland, of which the study of the phenomenon of Galicia, undertaken already while she was working in Ukraine, is of particular importance. Closely bound with it is the research on the problem of Ukrainian identity, discovered in Ukrainian literature of the 20th century. This novel research and quest for national identity, sought in the independent and anti-totalitarian thought permeating works of Ukrainian literature, were advanced by Andrusiw in Poland. What is also emphasised is the methodological framework employed by Professor Andrusiw in her articles published in journals and collections, including currents of thought new to Slavic studies: postmodernism, intertextuality and postcolonialism

Key words: Stefania Andrusiw, postmodernism, postcolonialism, intertextuality

\section{"ПОЛЬСЬКА" НАУКОВА СПАДЩИНА СТЕФАНІЇ АНДРУСІВ: ІЗ ДОСЛІДЖЕНЬ 3 ІСТОРІЇ УКРАЇНСЬКОЇ ЛІТЕРАТУРИ}

Анотація. Метою даної статті є висвітлити наукову постать професор Стефанії Андрусів - видатного літературознавця та літературного критика, тривалий час зв'язаної і Інститутом слов'янської філології Люблінського католицького університету Іоанна Павла II (2001-2013). Головною темою роздумів авторки стали літературні 
дослідження, які С. Андрусів проводила в Польщі, а також обговорення що основних напрямів літературознавчих досліджень української вченої, які виникли під час перебування в Любліні.

Авторка підкреслює велике значення галицького феномену в дослідженнях С. Андрусів, які вона розпочала ще до приїзду в Польщу. Із цією темою невід'ємно пов'язувалася також рефлексія з приводу української ідентичності, що відкривалася українській літературі XX століття. Згадані новаторські дослідження, пошуки, показування незалежної, антитоталітарної думки в українській літературі, розгорталися та розвивалися під час роботи в Польщі. У даній статті було звернено увагу на такі напрямки пошуків як постмодернізм, постколоніалізм та інтертекстуальність, які професор Андрусів пропонувала в багатьох статтях, що друкувалися як в багатоавторських монографіях, так і у наукових часописах.

Ключові слова: Стефанія Андрусів, постмодернізм, постколоніалізм, інтертекстуальність. 